\title{
Intersection of Chlorella, Muriella and Bracteacoccus: Resurrecting the genus Chromochloris Kol et ChODAт (Chlorophyceae, Chlorophyta)
}

\author{
Karolina FuČíKOvÁ* \& Louise A. LEWIS \\ University of Connecticut Department of Ecology and Evolutionary Biology, University of Connecticut, 75 North \\ Eagleville Road, Storrs, 06269-3043 USA; *corresponding author e-mail: karolina.fucikova@uconn.edu
}

\begin{abstract}
Coccoid green algae generally are difficult to classify because of their depauperate morphology, and for this reason many of them have a complicated taxonomic history. In the present study we use analyses of molecular sequence data to demonstrate the close relationship of two green coccoid taxa that have undergone multiple taxonomic transfers in the past, and argue for the recognition of a distinct lineage. We resurrect the genus Chromochloris to accommodate C. zofingiensis (= Muriella zofingiensis) and we provide data regarding the lineage's phylogenetic relationships to other chlorophyte genera, especially Bracteacoccus, Chlorella, Muriella, Mychonastes, and Pseudomuriella. In addition, we synonymize B. cinnabarinus and Bracteacoccus minutus with C. zofingiensis, and clarify the identity of three UTEX strains heretofore listed as Bracteacoccus.
\end{abstract}

Key words: $18 \mathrm{~S}$, Bracteacoccus cinnabarinus, cryptic taxa, ITS, rbcL, tufA

\section{Introduction}

It is not uncommon for a single taxon to undergo several transfers among two or more genera, for its name to be synonymized with another name and then subsequently be reinstated. Coccoid green algae are notorious for their extremely confused taxonomic histories (LEwIS \& McCourt 2004), and more revisions are needed in order to accommodate new findings about their diversity and systematic relationships. Viewed under a light microscope, the simple phenotypes of coccoid algae offer few traits for taxonomic use. Even with morphological characters available, the interpretation of these characters is subjective and different authors may consider different traits taxonomically important. DNA sequences offer hundreds of characters and thus provide abundant and independent data to evaluate evolutionary histories of organisms, for which morphological characters are scarce, invariable or plastic, or in which morphological homoplasy may be common.

The genus Chromochloris as described by KOL \& CHODAT (1934) comprises a single species Chromochloris cinnabarina Kol et CHODAT, a soil alga producing striking amounts of red carotenoid pigments in aging cultures. This species was transferred to the genus Dictyococcus GERNECK by VISCHER (1936), and later into Bracteacoccus Tereg by Starr (1955). However, EtTL \& GärtNER (1995) argued against accepting Bracteacoccus cinnabarinus (Kol et CHODAT) STARR because this species was described as uninucleate, whereas the genus Bracteacoccus is characterized by multinucleate cells. To date, this alga is regarded as a member of Bracteacoccus (GUIRY \& GUIRY 2011) and the original culture of this species is available from public culture collections (UTEX 56 , SAG 221-2). The systematic affinity of this taxon was the main focus of the present study. Two additional coccoid taxa of uncertain phylogenetic position, B. minutus SCHWARZ and Muriella zofingiensis (DöNZ) HINDÁK, were examined in order to determine their phylogenetic positions within the Chlorophyceae.

Bracteacoccus minutus, a species of a small size and containing numerous tiny chloroplasts, was described from soil from Dalmatia, Yugoslavia (now Croatia) (SchwARZ 1979), without designation of type material. While this makes the name invalid, Schwarz's original culture still exists and is available from the University of Innsbruck Culture Collection (ASIB S223). Therefore the taxonomic identity of $B$. minutus can be verified and a type may be 
designated if evidence is found for this strain to represent a new, distinct species.

Muriella zofingiensis (strain SAG 211-14 or its duplicates ATCC 30412 and UTEX 32) has been the target of several physiological studies particularly due to its potential for secondary carotenoid production (e.g., Ip \& CHEN 2005; HuANG et al. 2006; Li et al. 2006). The taxonomic and phylogenetic affiliation of this species also has received considerable attention. It was originally described as Chlorella zofingiensis (DöNZ 1934); then transferred into the genus Muriella by HindÁK (1982) based on detailed light microscopic morphological and life-cycle observations. In 1987, KaLINA \& PUNČOCHÁŘovÁ argued for the transfer of M. zofingiensis (DöNZ) HINDÁK into the genus Mychonastes, based on their observations from scanning- and transmissionelectron microscopy. Today, the species is regarded as a member of the genus Muriella (GUIRY \& GUIRY 2011). In HindÁk (1982), Muriella aurantiaca VISCHER was synonymized with $M$. zofingiensis (DöNZ) HINDÁK, but it has since been demonstrated that $M$. aurantiaca belongs in a separate chlorophycean genus, Pseudomuriella (Hanagata 1998; FučíKovÁ et al. 2011) and that M. zofingiensis is a lineage distinct from Muriella (Kalina \& PunČocháŘová 1987; Hanagata 1998), Mychonastes (KRIENITZ et al. 2011), and Chlorella sensu stricto (Huss et al. 1999).

As part of a larger molecular-phylogenetic work focused on the genus Bracteacoccus, several strains bearing this generic name were demonstrated to belong to lineages distinct from Bracteacoccus (unpublished data). A previous study focused on one of these lineages, the genus Pseudomuriella Hanagata, to which two former Bracteacoccus species [B. engadinensis (Kol et CHODAT) STARR and B. terrestris (Kol et CHODAT) STARR] were transferred (FuČíKovÁ et al. 2011). In the present study, we sought to determine phylogenetic relationships of the putatively misclassified Bracteacoccus cinnabarinus, B. minutus and Muriella zofingiensis, taking advantage of the available type cultures. Additionally, we examined three UTEX extreme environment (EE) strains from the Negev Desert (Israel) - UTEX EE76, EE82, and EE83, all designated as Bracteacoccus sp. - to determine their phylogenetic affiliations.

This study serves as an example of a common problem: unclear relationships among morphologically poor organisms, their tangled taxonomic histories and conflicting arguments about their affiliations, which in some cases are further complicated by the absence of live type material and/or improper typification. Our study is among the first contributions to green coccoid systematics that attempt to settle such taxonomic confusion through the use of molecularphylogenetic analyses (e.g., Neustupa et al. 2009; Bock et al. 2010; ŚKALOUd \& PeKsa 2010; KRIENITZ et al. 2011).

\section{Materials and Methods}

All examined cultures were grown on Bold's Basal Medium (BBM, Bold 1949; BISChoff \& Bold 1963) and $\mathrm{BBM}$ enriched with soil water extract, under 16:8 light:dark cycle at $18{ }^{\circ} \mathrm{C}$ and $70 \mu \mathrm{mol} . \mathrm{m}^{2} . \mathrm{s}^{-1}$. Morphology was examined using an Olympus BX60 light microscope with Nomarski's DIC optics. Fluorescent staining with DAPI and Syto11 was carried out following the protocol of ZACHLEDER \& CЕРÁK (1987), and using a Zeiss Axioskop2 for observation.

The genes of interest were the nuclear small subunit (18S) rRNA gene, which is commonly used in green algal systematic studies, and the increasingly popular plastid gene encoding the large subunit of ribulose 1,5-bisphosphate carboxylase/oxygenase (rubisco), $r b c \mathrm{~L}$, shown to perform well at the genusand species-level (Rind et al. 2007). We used the $18 \mathrm{~S}$ gene to determine the relationships of the strains of interest to chlorophycean and trebouxiophycean genera, in which they had been classified previously: Bracteacoccus Tereg, Chlorella BeIJerinck, Muriella Petersen, and Mychonastes Simpson et VAN VALKENBURG. We also included other taxa putatively related to the strains of interest in our analyses: e.g., Dictyococcus Gerneck, Planktosphaeria G.M. Smith, Pseudomuriella Hanagata, and Radiococcus SCHMidLE, which were selected based on similarities in gross morphology. The $r b c \mathrm{~L}$ data were used for a finerscale analysis focused on the Chlorophyceae. Two other variable markers were used to assess diversity within the newly characterized lineage: the nuclear ribosomal internal transcribed spacer 2 (ITS2), the utility of which for species-level taxonomy is reviewed in Coleman (2003), and the plastid-encoded gene for the elongation factor TU (tufA), another promising, although not-yet widely utilized, species-level marker (FAMA et al. 2002).

DNA was isolated using the PowerPlant DNA Isolation Kit (Mo Bio Laboratories, Inc., Carlsbad, CA, USA). Primers from Shoup \& Lewis (2003) were used for the $18 \mathrm{~S}$ gene, with PCR conditions as follows: $94{ }^{\circ} \mathrm{C}$ for $1 \mathrm{~min}, 54^{\circ} \mathrm{C}$ for $45 \mathrm{~s}, 72{ }^{\circ} \mathrm{C}$ for 1 $\min 45 \mathrm{~s}$, repeated 27 times and followed by a final extension at $72^{\circ} \mathrm{C}$ for $8 \mathrm{~min} 15 \mathrm{~s}$. Primers used for PCR 
Table 1. Strains of algae used in the combined $18 \mathrm{~S}+r b c \mathrm{~L}$ phylogenetic analysis with their GenBank accession numbers. Italicized strain numbers indicate type strains. Accessions highlighted in boldface were obtained in the present study. [(UTEX) Culture Collection of Algae at the University of Texas, Austin TX, USA; (SAG) Culture Collection of Algae, Göttingen, Germany; (CCAP) Culture Collection of Algae and Protozoa, Oban, Scotland; (ASIB) Algae Collection at the Institute of Botany, Innsbruck, Austria; (BCP) Biotic Crust Project (http://pediastrum.eeb.uconn.edu/)].

\begin{tabular}{|c|c|c|c|}
\hline Taxon & Strain \# & $18 \mathrm{~S}$ & $r b c \mathrm{~L}$ \\
\hline Bracteacoccus giganteus & UTEX 1251 & U63099 & EF113414 \\
\hline Bracteacoccus minor & UTEX 66 & U63097 & GQ985399 \\
\hline Bracteacoccus pseudominor & UTEX 1247 & GQ985405 & GQ985397 \\
\hline Bracteacoccus sp. & BCP BC2-1 & AF516676 & GQ985401 \\
\hline Planktosphaeria gelatinosa & SAG $262-1 b$ & AY044648 & HM852435 \\
\hline Radiococcus polycoccus & SAG $217-1 \mathrm{c}$ & AF388378 & HM852437 \\
\hline Pseudomuriella aurantiaca & CCAP 249/1 & $\mathrm{AB} 005748$ & HM852438 \\
\hline Pseudomuriella cubensis & $K F 2$ & HQ292770 & HQ292739 \\
\hline Pseudomuriella engadinensis & UTEX 57 & HM852441 & HM770958 \\
\hline Pseudomuriella schumacherensis & UTEX 2252 & HM852439 & HM852434 \\
\hline Bracteacoccus cinnabarinus & UTEX 56 & HQ902933 & HQ902939 \\
\hline Muriella zofingiensis & $S A G 211-14 a$ & X74004 & HQ902940 \\
\hline Bracteacoccus minutus & ASIB S223 & HQ902934 & HQ902941 \\
\hline Pediastrum duplex & UTEX 1364 & AY779859 & EF113461 \\
\hline Hydrodictyon africanum & UTEX LB-762 & AY663031 & EF078304 \\
\hline Neochloris aquatica & UTEX 138 & M62861 & EF113456 \\
\hline Dictyococcus varians & $U T E X L B-62$ & GQ985408 & GQ985404 \\
\hline Scenedesmus rotundus & BCP SEV3VF49 & AF513373 & HQ246350 \\
\hline Ankistrodesmus stipitatus & SAG 202-5 & X56100 & EF113406 \\
\hline Ourococcus multisporus & UTEX 1240 & AF277648 & EF113460 \\
\hline Mychonastes jurisii & SAG 37.98 & AF106074 & AF321101 \\
\hline
\end{tabular}

amplification and cycle sequencing of $r b c \mathrm{~L}$ are listed in McManus \& Lewis (2011). PCR conditions for the amplification of $r b c \mathrm{~L}$ were as follows: $94{ }^{\circ} \mathrm{C}$ for $1 \mathrm{~min}$ $15 \mathrm{~s}, 56^{\circ} \mathrm{C}$ for $2 \mathrm{~min}, 72^{\circ} \mathrm{C}$ for $2 \mathrm{~min} 15 \mathrm{~s}$, repeated 30 times and followed by a final extension at $72{ }^{\circ} \mathrm{C}$ for 7 $\min$. The ITS region was amplified using primers from White et al. (1990) and Shoup \& Lewis (2003), and PCR cycle of $94{ }^{\circ} \mathrm{C}$ for $1 \mathrm{~min} 15 \mathrm{~s}, 52{ }^{\circ} \mathrm{C}$ for $1 \mathrm{~min}$, $72{ }^{\circ} \mathrm{C}$ for $1 \mathrm{~min} 45 \mathrm{~s}$ repeated 30 times and followed by a final extension step at $72{ }^{\circ} \mathrm{C}$ for $4 \mathrm{~min}$. The tufA region was amplified using the protocol of FAMA et al. (2002). The sequencing cycle comprised 27 cycles of denaturing at $96^{\circ} \mathrm{C}$ for $30 \mathrm{~s}$, annealing at $50^{\circ} \mathrm{C}$ for $15 \mathrm{~s}$, and extension at $60{ }^{\circ} \mathrm{C}$ for $4 \mathrm{~min}$, using the Big Dye $\mathrm{P}^{\mathrm{TM}}$ Terminator Cycle Sequencing Reaction Kit (Applied Biosystems, Foster City, CA, USA). Products of cycle sequencing were cleaned using ethanol precipitation and analyzed on ABI 3100 DNA Sequencer ${ }^{\mathrm{TM}}$ (Applied Biosystems, Foster City, CA, USA).

Strains used and their GenBank accession numbers for the genes collected are listed in Table 1. Additional strains used in the $18 \mathrm{~S}$ analysis and their GenBank numbers were: Bulbochaete rectangularis var. hiloensis (U83132), Chaetopeltis orbicularis (U83125), Chaetophora incrassata (UTEX LB-1289, D86499), Chlamydomonas reinhardtii (M32703), Chlorella ellipsoidea (SAG211-1a, X63520), Chlorella sorokiniana (SAG 211-8k, X62441), Chlorella vulgaris (SAG 211-11b, X13688), Chlorogonium elongatum (NIES 1358, AB278625), Desmodesmus subspicatus (UTEX 2532, AJ249514), Muriella sp. (AS2-4, AY195969), Muriella terrestris (ASIB V38, AB012845), Mychonastes homosphaera (CCAP 211/8e, X73996), Mychonastes sp. (NIES 2340, AB488567; NIES 2334, AB488564), Myrmecia astigmatica (IB-T76, Z47208), Myrmecia biatorellae (UTEX 907, Z28971), Myrmecia irregularis (CCAP 221/8, HQ902935), Myrmecia sp. (UTEX EE-76, HQ902936; UTEX EE-82, HQ902937; UTEX EE83, HQ902938), Neodesmus danubialis (SAG 17.81, 
AB037086), Oedogonium cardiacum (U83133), Oogamochlamys zimbabwiensis (UTEX 2214, AJ410472), Phacotus lenticularis (Kr91/1, X91628), and Volvox carteri (UTEX 1885, X53904). The ITS and tufA sequences used in the targeted study were deposited in GenBank under accession numbers HQ902927 - HQ902932.

The ITS2 secondary structure was estimated using tools available in the ITS2 database (KOETSCHAN et al. 2010) and sequences and structures from KELLER et al. (2008). The secondary structures were viewed and edited using the software 4SALE (SEIBEL et al. 2008) to determine whether the strains of interest differ from each other in secondary structure and/or are separated by compensatory base changes (CBCs).

Sequences were aligned manually and analyzed using PAUP* (SWOFFord 2002), GARLI (ZwICKL 2006), and MrBayes (Huelsenbeck \& Ronquist 2001; RonQuist \& HuelsenBeck 2003). Alignments are available from www.treebase.org (study \# 11180). Appropriate substitution models were chosen using jModeltest v0.1 (PosADA 2008) under the Akaike Information Criterion (AIC). The model selected for the $18 \mathrm{~S}$ data set was TIM2 $+\mathrm{I}+\mathrm{G}$, which is best approximated by GTR $+\mathrm{I}+\mathrm{G}$ in MrBayes. For the $r b c \mathrm{~L}$ data set, the $\mathrm{GTR}+\mathrm{G}$ model was selected under AIC. In the combined analysis, the two data sets were concatenated and analyzed under the $\mathrm{GTR}+\mathrm{I}+\mathrm{G}$ model both in Bayesian and ML framework. Bayesian analyses were run for $10^{7}$ generations with one cold chain and three heated chains, using two parallel runs in each analysis and sampling every 100 generations. The first $10 \%$ of samples were discarded as burnin. Parameter stability and run convergence were inspected using Tracer v1.4.1 (RAMBAUT \& DRUMMOND 2003) and AWTY (WiLgENBUSCH et al. 2004).

\section{Results}

\section{Morphological observations}

Cells of Bracteacoccus minutus (ASIB S223, Figs 1-5), Muriella zofingiensis (SAG 211-14a, Figs 6-10), and Bracteacoccus cinnabarinus (UTEX 56, Figs 11-15) do not take up DAPI or Syto11 readily (similarly to the genus Pseudomuriella observations in FučíKovÁ et al. 2011), but light microscopic observations suggest the presence of several nuclei in mature cells (Figs 5, 10, 15 - putative nuclei indicated by arrows). Mature cells contain multiple parietal chloroplasts and accumulate large quantities of lipids and red pigments in aging cultures (usually 4 months and older, Figs 4-5, 9-10, 14-15). Young cells (Figs $1,6,11)$ contain a single nucleus and a single parietal chloroplast, and resemble young cells of many other coccoid taxa (e.g., Bracteacoccus,

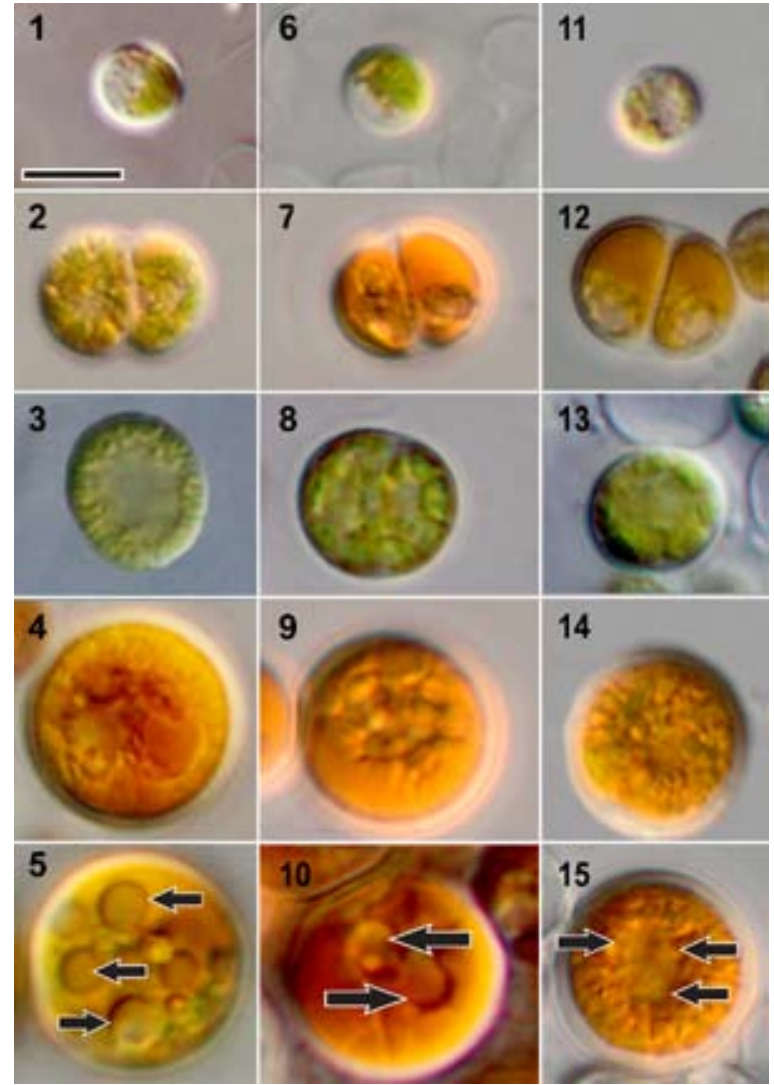

Figs 1-15. Light micrographs of examined strains: (1-5) Bracteacoccus minutus, strain ASIB S223; (6-10) Muriella zofingiensis, strain SAG 211-14; (11-15) Bracteacoccus cinnabarinus, strain UTEX 56; $(1,6,11)$ young cells; $(2,7$, 12) division into 2 autospores; $(3,8,13)$ mature cells from 3 week old cultures; $(4,9,14)$ mature cells from cultures $>$ 4 months old; $(5,10,15)$ Mature cells with multiple nuclei (black arrows). Scale bar represents $5 \mu \mathrm{m}$.

\section{Dictyococcus, Pseudomuriella, Chlorella).}

\section{Phylogenetic analyses}

The 18S data set comprised 1452 characters after exclusion of 69 characters of dubious homology, and the $r b c \mathrm{~L}$ data set comprised 1176 characters. All our phylogenetic analyses recovered a robust clade containing Bracteacoccus cinnabarinus, Bracteacoccus minutus, and Muriella zofingiensis. This lineage remained isolated and showed no strong affinity to any other sampled genus even when more chlorophycean sequences were added to the matrix (results not shown). It is likely a member of the group characterized by directly opposite flagellar basal bodies (DO clade sensu LEwIS \& McCourT 2004), although this affiliation did not receive high statistical support in the $18 \mathrm{~S}$ analyses (Fig. 16) and the lineage's phylogenetic position was not strongly resolved in the more focused $\mathrm{ML}$ analysis of combined $r b c \mathrm{~L}$ and $18 \mathrm{~S}$ 


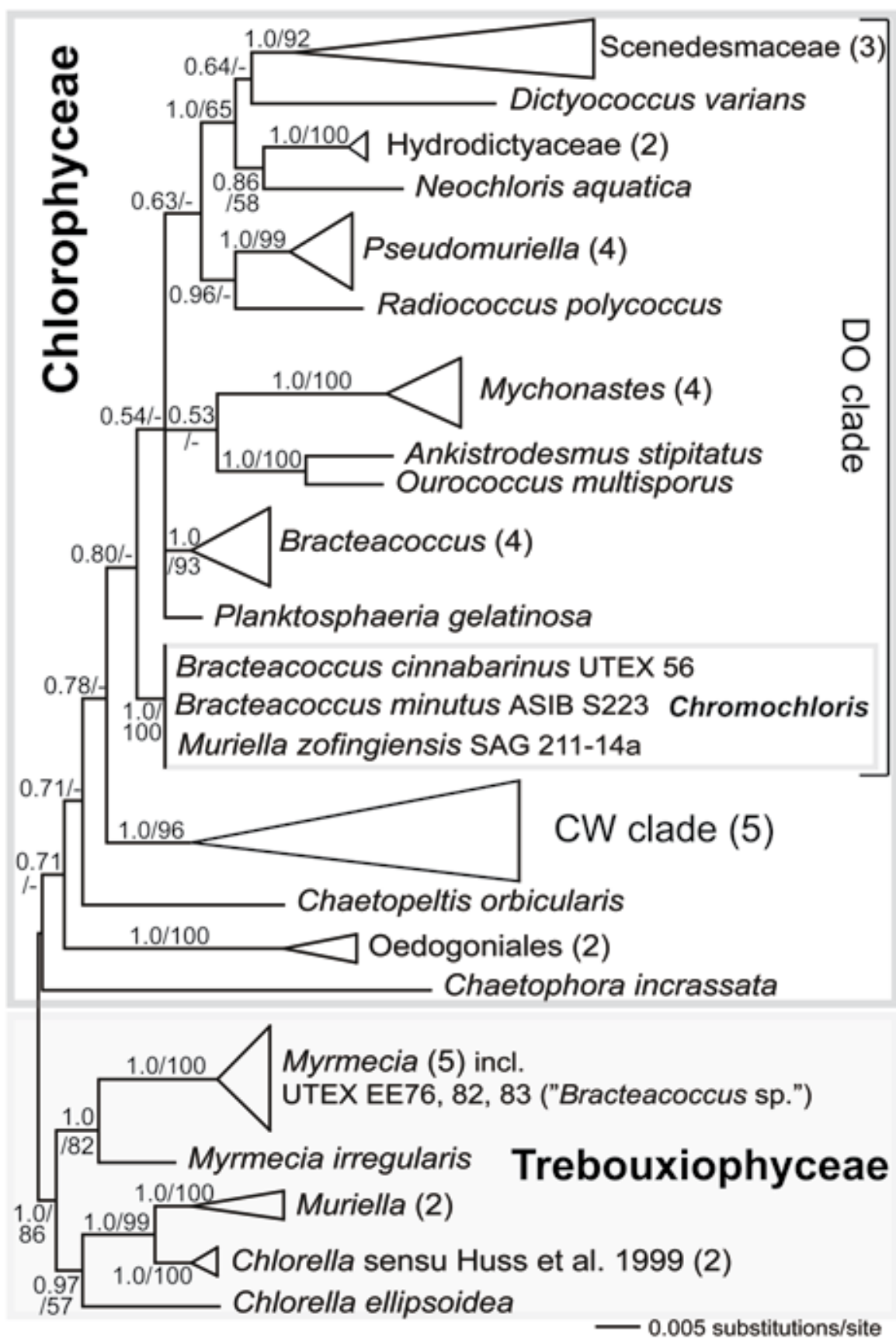

Fig. 16. Collapsed summary tree showing results of the Bayesian analysis of the $18 \mathrm{~S}$ data set (46 taxa) indicating the position and distinct character of the Chromochloris lineage. Also included are genera historically associated with Chromochloris. Numbers of taxa in collapsed clades are reported in parentheses. CW and DO refers to the configuration of the flagellar apparatus (clock-wise and directly opposed, respectively); CW and DO clades designated according to LEWIS \& MCCOURT (2004). Bayesian posterior probabilities (BPP) and ML bootstrap (BS) values indicate node support. Values lower than 0.50 $\mathrm{BPP}$ or $50 \mathrm{BS}$ are indicated by hyphens (-). Scale bar corresponds to the expected number of substitutions/site.

data (Fig. 17). The combined Bayesian analysis (Fig. 17) suggested this lineage as a member of a clade containing several othercoccoid polyplastidic genera: Bracteacoccus, Pseudomuriella, Radiococcus, and Planktosphaeria.

The three species-level markers $(r b c \mathrm{~L}$, ITS and $t u f$ A) revealed some variation within the lineage containing Bracteacoccus cinnabarinus, $B$. minutus, and Muriella zofingiensis. Bracteacoccus minutus and M. zofingiensis differed in $0.15 \%$ of the full ITS region (659 bp total, including ITS1, $5.8 \mathrm{~S}$ and ITS2) and in $0.24 \%$ of the tufA gene (849 bp total), and were identical in $r b c \mathrm{~L}$ sequence. These two species composed the sister group to $B$. cinnabarinus, from which they differed in 1.21$1.37 \%$ of ITS sites, $1.30-1.53 \%$ of tufA sites, and 


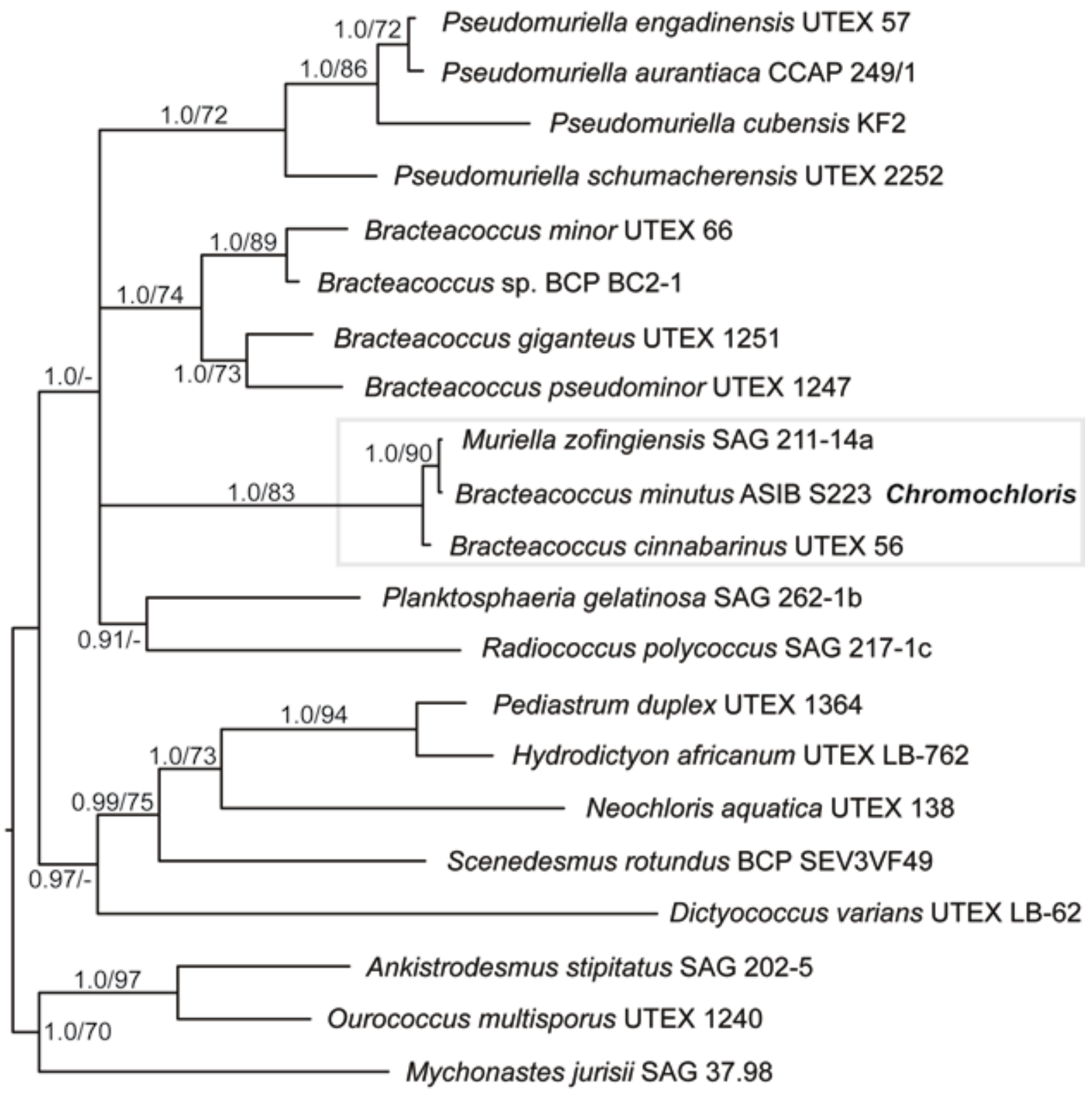

0.02 substitutions/site

Fig. 17. Bayesian phylogenetic tree based on the combined analysis of $18 \mathrm{~S}$ and $r b c \mathrm{~L}$ data set, indicating relationships of Chromochloris to other genera with similar morphology. BPP and ML BS values indicate node support. Values lower than 0.50 $\mathrm{BPP}$ or $50 \mathrm{BS}$ are indicated by hyphens (-). Scale bar corresponds to the expected number of substitutions/site.

$0.60 \%$ of $r b c \mathrm{~L}$ sites. No CBCs separating any two of the three strains were found in the ITS2 region (Fig. 18). B. cinnabarinus differed from the remaining two strains, which were identical in ITS2, in 6 ITS2 sites (Fig. 18).

The three UTEX EE strains designated as Bracteacoccus sp. were placed in the class Trebouxiophyceae with high node support values in our $18 \mathrm{~S}$ analyses (Fig. 16). These isolates were resolved in a clade that otherwise contained species of the genus Myrmecia, and appeared to be close relatives of $M$. astigmatica and $M$. israelensis. These algae are of roughly Bracteacoccus-like morphology, but were not examined in detail, as this was outside of the scope of the present study. We merely report that they do not belong in Bracteacoccus (or related genera), despite being labeled as such in the UTEX collection. It also should be noted that there are two other EE "Bracteacoccus" strains available from UTEX: one, UTEX EE80 is a true Bracteacoccus, whereas UTEX EE84 is a trebouxiophyte of unknown 


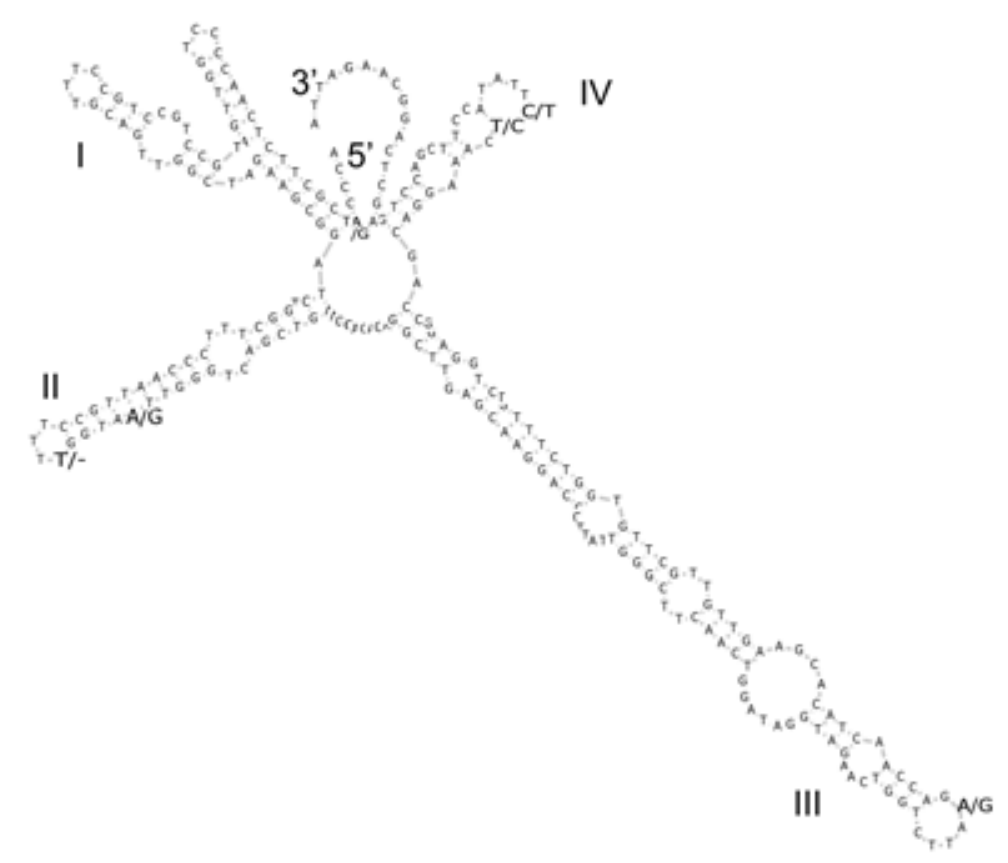

Fig. 18. Predicted ITS2 secondary structure of Chromochlo-ris (UTEX 56) with sites variable within the genus highlighted in larger font (e.g., A/G indicates A in UTEX56 and $\mathrm{G}$ in SAG 211-14a and ASIB S223). Individual helices (stems) are indicated by roman numerals. affiliation (unpublished observations).

\section{Discussion}

\section{Morphological observations}

Bracteacoccus cinnabarinus, described in KoL $\&$ Chodat (1934), is a soil alga isolated from Engadine Nat. Park, Switzerland. The cells are small (up to $12 \mu \mathrm{m}$ ) and spherical with a fairly robust cell wall in maturity, and accumulate large quantities of orange to reddish pigments as they age. Reproduction occurs via 4-16 autospores or many small zoospores. The type strain, UTEX 56 , corresponds morphologically to the original circumscription with the exception of the number of nuclei. While Kol \& Chodat (1934) reported uninucleate cells, our observations suggested several nuclei in mature cells. This trait may be difficult to observe, as the cell content is often obscured by abundant secondary pigments. We do not consider this discrepancy significant and we do not think there is a reason to question the identity/ authenticity of the strain, since its morphology otherwise matches the original description very well. No zoospores were observed in the present study.

The morphology and reproduction of Bracteacoccus minutus are very similar to $B$. cinnabarinus (described above). The species, however, was circumscribed as multinucleate (SCHWARz 1979) and zoospore morphology and plastid development in vegetative cells were described in more detail. According to SCHWARZ (1979), young cells possess $1-4$ thin parietal chloroplasts, which in older cells become thicker and break up into numerous small pieces. The zoospores are naked, elongate, and lack a stigma. Their flagella are of slightly uneven length, a trait otherwise typical for the genus Bracteacoccus (StARR 1955). Although no zoospores were observed in the present study, the vegetative morphology of the strain ASIB S223 was found consistent with the original description.

Muriella zofingiensis was originally placed in the genus Chlorella (Dönz 1934) and was only reported to reproduce via autospores. The affinity to Chlorella was justified mainly by the presence of a single hollow-spherical chloroplast. However, this observation was later overruled by HINDÁK (1982), who reported numerous plastids in adult cells, only to be questioned again by KaLINA \& PunčochÁŘová (1987) who suggested a single, highly lobed plastid based in their TEM observations. Neither of the 1980's studies reported zoospores or specifically mentioned the number of nuclei. The plastid number is a trait difficult to observe, especially in older cells where abundant carotenoids are present and obscure the view of mature plastids. In the present study, LM observations suggested the presence of numerous small chloroplasts. The overall morphology of the authentic strain SAG 211-14a was otherwise consistent with the original description of the species.

In summary, the morphological features of 
the three strains of interest observed in the present study were generally consistent with the original descriptions associated with the strains. Although there were some discrepancies among the three species circumscriptions, these can be explained by more recent data and different interpretations of morphological features by various authors. Overall, the three species' morphologies are very similar.

\section{Phylogenetic analyses}

The three coccoid algae, Bracteacoccus cinnabarinus, B. minutus and Muriella zofingiensis, composed a strongly supported monophyletic lineage that was phylogenetically distinct from all other examined genera, including those that had played a role in the taxonomic histories of these three species: Bracteacoccus, Chlorella, Dictyococcus, Muriella, and Mychonastes (Figs 16, 17). Our study strongly suggests that the original recognition of Chromochloris cinnabarina as a member of a new genus was correct. Therefore, we here resurrect Chromochloris to make this generic name available for Bracteacoccus cinnabarinus, as it is the most appropriate name for this species. We provide an emended diagnosis for Chromochloris along with designating a lectotype specimen for the type species, C. cinnabarina. Additionally, we propose the transfer of M. zofingiensis to the genus Chromochloris (see Taxonomic Implications below).

In our combined Bayesian analysis of the $r b c \mathrm{~L}$ and $18 \mathrm{~S}$ data, the multinucleate, pyrenoidlacking Chromochloris were resolved in the proximity of other genera with similar gross morphology (all multinucleate, polyplastidic and vegetatively spherical): the pyrenoid-lacking Bracteacoccus and Pseudomuriella, and the pyrenoid-possessing Planktosphaeria and Radiococcus (Figs 16, 17). All members of these genera have been reported to reproduce by naked zoospores (STARR 1954; BISCHOFF \& BOLD 1963; Kalina \& PunČocháR̆ová 1987; Ettl \& Gärtner 1995), although the predominant form of asexual reproduction in Pseudomuriella appears to be autospore production (FučíkovÁ et al. 2011). This grouping suggests a deep origin of the spherical, multinucleate polyplastidic morphology for these algae. This morphology also occurs elsewhere in the green algal phylogeny (e.g., in Dictyococcus), indicating either multiple independent acquisitions of this morphology or multiple losses thereof. It is not discernible whether pyrenoid loss or gain occurred only once or multiple times. Additional analyses with denser taxon sampling will be needed to address these issues. It should be noted that this grouping of morphologically similar taxa was not strongly supported by our ML bootstrap analyses.

All three representatives of Chromochloris examined are prolific producers of secondary carotenoid pigments, and turn brick-red in older cultures. While young cells are green in color and uninucleate, mature cells contain multiple small parietal chloroplasts and are likely multinucleate, contrary to the original circumscription of $C$. cinnabarina (Kol \& CHODAT 1934). The genus is virtually indistinguishable morphologically from Pseudomuriella, except for the slightly darker (brick-red rather than orange) color of aging cultures. This is possibly a case of cryptic genera: Pseudomuriella and Bracteacoccus lack a clear trait distinguishing one from the other, except for the property that Pseudomuriella cells do not take up fluorescent dyes readily. Chromochloris, like Pseudomuriella, does not allow the penetration of fluorescent dyes. A similar case of morphologically indistinguishable genera has recently been published by Bock et al. (2010) for Dictyosphaerium NäGELI, and Heynigia Bock, PRÖSCHOLD et KRIENITZ.

The observed morphological and genetic variation within the genus Chromochloris is very small and justifies, in our opinion, the recognition of a single species, C. zofingiensis (published in May 1934), which has priority over C. cinnabarina (published in September 1934). We therefore propose to synonymize the two taxon names. Because no type was selected in the original publication by Kol \& CHODAT (1934), we designate a lectotype below. The genus name should be tied to the material originally used to diagnose Chromochloris, which is the strain UTEX 56 (C. cinnabarina), even though C. cinnabarina is here synonymized with $C$. zofingiensis (Article 10.3 of the Vienna Code-McNeill et al. 2006). The third strain examined here, Bracteacoccus minutus, is genetically nearly identical to $C$. zofingiensis and should therefore be included in this species. SchwARZ's (1979) publication of B. minutus is not valid, as no type specimen was designated (Article 37.1 of the Vienna Code - McNeILl et al. 2006), and indeed no passage in the article itself unambiguously links the isolate ASIB S223 to the publication. Therefore, no formal taxonomic change is required to deal with this strain. 
Because Muriella zofingiensis has been used as a model organism for various physiological studies (IP \& Chen 2005; HuANG et al. 2006; Li et al. 2006; PelaH \& CoHen 2005), the clarification of its phylogenetic affiliation and identification of its closest relatives may be helpful for future physiological research. For instance, strains ASIB S223 and UTEX 56 may be ideal candidates for further similar studies, while it would be of no use searching for such candidates in Chlorella, Muriella, or Mychonastes. This is an example of the importance of correct taxonomy/systematics for applied research.

The findings reported in the present study clarify the taxonomy of the examined strains and demonstrate the utility of molecular sequence data in morphologically poor organisms. Even though informative morphological characters may exist in these organisms, perhaps on an ultrastructural level, or ones detectable by methods unexplored in this study, the decreasing cost and relative ease of DNA sequencing make this tool a convenient complement to morphological methods.

\section{Taxonomic Implications:}

\section{Chromochloris Kol et ChODAT}

Alga unicellularis et solitaria. Cellulae sphaericae vel ovoideae. Paries cellulae laevis. Cellulae juvenes uninucleatae; cellulae maturae multinucleatae. Chloroplasti multiplices, parietales, pyrenoide carentes. Reproductio autosporis, rare zoosporis. Substantiae carotenoides secundae praesentes in abundantia. Cultura senescens coloris testacei. Species typica: Chromochloris cinnabarina KoL \& CHODAT 1934 syn. C. zofingiensis (DöNZ) FUČ́KOVÁ et LEWIS.

Lectotypus: cultura algarum cryopreservata UTEX 56, University of Texas, Austin, TX, U.S.A.

Alga unicellular, solitary. Cells spherical or oval. Cell wall smooth. Young cells uninucleate; mature cells multinucleate. Multiple parietal chloroplasts lacking a pyrenoid. Reproduction via autospores, rarely via zoospores. Secondary carotenoids present in abundance. Aging culture colored brick-red.

Type species: Chromochloris cinnabarina KoL et Chodat 1934 syn. C. zofingiensis (Dönz) FuČíKOVÁ et LEWIS.

Lectotype: cryopreserved culture UTEX 56, University of Texas, Austin, TX, U.S.A.
Chromochloris zofingiensis (DöNz) Fučíková et LEwIS comb. nov. (Figs 6-10)

Basionym: Chlorella zofingiensis DöNz 1934, Ber. Schweiz. Bot. Ges. 43, p. 127, fig. 1.

Synonyms: Muriella zofingiensis (DöNz) HindÁK 1982, Algological Studies 40, p. 22; Mychonastes zofingiensis (Dönz) Kalina et Punčochářová 1987, Algological Studies 45, p. 512; Bracteacoccus minutus nom. inval. Schwarz 1979, Plant Syst. Evol. 131, p. 202, fig. 5, Chromochloris cinnabarina Kol et CHоDAт 1934, Bull. Soc. Bot. Genève 25, p. 255, figs 30 - 56 .

Lectotype: cryopreserved culture SAG 21114a, Culture Collection of Algae, Göttingen, Germany.

\section{Acknowledgements}

Many thanks to Dr. Georg Gärtner (Univ. Innsbruck) for kindly providing the culture of Bracteacoccus minutus, Dr. Thomas Friedl (Univ. Göttingen) for providing the type culture of Muriella zofingiensis, Dr. Michael Wynne (Univ. of Michigan Herbarium) for determining exact publication dates of $B$. cinnabarinus and M. zofingiensis, and Drs. Nicholas Tippery, Bernard Goffinet, Kent Holsinger, and an anonymous reviewer for providing valuable feedback on the manuscript. This work was supported by a grant from the National Science Foundation (DEB-0529737) awarded to Louise A. Lewis.

\section{References}

Bischoff, H.W. \& Bold, H.C. (1963): Phycological studies IV. Some soil algae from Enchanted Rock and related algal species. - Univ. Texas Publ. 6318: 1-95.

Bock, C.; Pröschold, T. \& Krienitz, L. (2010): Two new Dictyosphaerium-morphotype lineages of the Chlorellaceae (Trebouxiophyceae): Heynigia gen. nov. and Hindakia gen. nov. Eur. J. Phycol. 45: 267-277.

Bold, H.C. (1949): The morphology of Chlamydomonas chlamydogama sp. nov. - Bull. Torr. Bot. Club 76: 101-8.

Coleman, A.W. (2003): ITS2 is a double-edged tool for eukaryote evolutionary comparisons. - TIG 19: 370-375.

Dönz, O.C. (1934): Chlorella zofingiensis, eine neue Bodenalge. - Ber. Schweiz. Bot. Ges. 43: 127131.

EtTL, H. \& Gärtner, G. (1995): Syllabus der Boden-, Luft- und Flechtenalgen. - 722 pp., Gustav Fischer Verlag, Stuttgart, Jena, New York.

Fama, P.; Wysor, B.; KoOISTRA, W.H.C.F. \& ZucCarello, G.C. (2002): Molecular phylogeny of the genus 
Caulerpa (Caulerpales, Chlorophyta) inferred from chloroplast tufA gene. - J. Phycol. 38: 1040-1050.

FučíKovÁ, K.; RadA, J.C. \& Lewis, L.A. (2011): The tangled taxonomic history of Dictyococcus, Bracteacoccus, and Pseudomuriella (Chlorophyceae, Chlorophyta) and their distinction based on a phylogenetic perspective. - Phycologia 50: 422-429.

Guiry, M.D. \& Guiry, G.M. (2011): AlgaeBase. Worldwide electronic publication, National University of Ireland, Galway. http://www.algaebase.org; searched on 27 January 2011.

Hanagata, N. (1998): Phylogeny of the subfamily Scotiellocystoideae(Chlorophyceae) and related taxa inferred from $18 \mathrm{~S}$ ribosomal RNA gene sequence data. - J. Phycol. 34: 1049-1054.

HindÁK, F. (1982): Taxonomic position of the chlorococcal alga Chlorella zofingiensis Dönz 1934 (Chlorophyceae). - Algological Studies 40: 13-23.

Huang, J.C.; Wang, Y.; Sandmann, G. \& Chen, F. (2006): Isolation and characterization of a carotenoid oxygenase gene from Chlorella zofingiensis (Chlorophyta). - Appl. Microbiol. Biotechnol. 71: 473-479.

Huelsenbeck, J. P. \& Ronquist, F. (2001): MRBAYES: Bayesian inference of phylogeny. Bioinformatics 17: 754-755.

Huss, V.A.R.; Frank, C.; Hartmann, E.C.; Hirmer, M.; KlobouceK, A.; Seidel, B.M.; Wenzeler, P. \& Kessler, E. (1999): Biochemical taxonomy and molecular phylogeny of the genus Chlorella sensu lato (Chlorophyta). - J. Phycol. 35: 587598.

IP, P.F. \& ChEn, F. (2005): Production of astaxanthin by the green microalga Chlorella zofingiensis in the dark. - Process Biochem. 40: 733-738.

Kalina,T. \& PunčocháŘová, M. (1987): Taxonomy of the subfamily Scotiellocystoideae Fott 1976 (Chlorellaceae, Chlorophyceae). - Algological Studies 45: 473-521.

Keller, A.; Schleicher, T.; Förster, F.; Ruderisch, B.; Dandekar, T.; Müller, T. \& Wolf, M. (2008): ITS2 data corroborate a monophyletic chlorophycean DO-group (Sphaeropleales). BMC Evol. Biol. 8: 218.

Koetschan, C.; Förster, F.; Keller, A.; Schleicher, T.; Ruderisch, B.; Schwarz, R.; Müller, T.; Wolf, M. \& Schultz, J. (2010): The ITS2 Database III - sequences and structures for phylogeny. Nucleic Acids Res. 38: D275-279.

Kol, E. \& Chodat, F. (1934): Quelques algues nouvelles des sols et de la neige du Parc National Suisse, Engadine. - Bull. Soc. Bot. Genève 25: 250263.

Krienitz, L.; Bock, C.; Dadheech, P.K. \& Pröschold, T. (2011): Taxonomic reassessment of the genus
Mychonastes (Chlorophyceae, Chlorophyta) including the description of eight new species. - Phycologia 50: 89-106.

Lewis, L.A. \& McCourt, R.M. (2004): Green algae and the origin of land plants. - Am. J. Bot. 91: 1535-1556.

LI, H.B.; FAn, K.W. \& Chen, F. (2006): Isolation and purification of canthaxanthin from the microalga Chlorella zofingiensis by high-speed counter-current chromatography. - J. Sep. Sci. 29: 699-703.

McManus, H.A. \& Lewis, L.A. (2011): Molecular phylogenetic relationships in the freshwater family Hydrodictyaceae (Sphaeropleales, Chlorophyceae), with an emphasis on Pediastrum duplex. - J. Phycol. 47: 152163.

McNeill, J.; Barrie, F. R.; Burdet, H. M.; Demoulin, V.; Hawksworth, D. L.; Marhold, K.; Nicolson, D. H.; Prado, J.; Silva, P. C.; Skog, J. E.; Wiersema, J. H. \& Turland, N. J. (2006): International code of botanical nomenclature (Vienna code). Regnum Vegetabile 146. - 568 pp., A.R.G. Gantner Verlag KG.

Neustupa, J.; NĚmcová, Y.; Eliáš, M. \& ŠKaloud, P. (2009): Kalinella bambusicola gen. et sp. nov. (Trebouxiophyceae, Chlorophyta), a novel coccoid Chlorella-like subaerial alga from Southeast Asia. - Phycol. Res. 57: 159-169.

Pelah, D. \& Cohen, E. (2005): Cellular response of Chlorella zofingiensis to exogenous selenium. Plant Growth Regulation 45: 225-232.

PosadA, D. (2008): jModelTest: Phylogenetic model averaging. - Mol. Biol. Evol. 25: 1253-1256.

Rambaut, A. \& Drummond, A. (2003): Tracer: MCMC trace analysis tool. University of Oxford; Oxford, UK.

Rindi, F.; McIvor, L.; Sherwood, A.R.; Friedl, T.; Guiry, M.D. \& Sheath, R.G. (2007): Molecular phylogeny of the green algal order Prasiolales (Trebouxiophyceae, Chlorophyta). - J. Phycol. 43:811-822.

Ronquist, F. \& HuELSENBECK, J.P. (2003): MRBAYES 3: Bayesian phylogenetic inference under mixed models. - Bioinformatics 19:1572-1574.

Seibel, P.N.; Müller, T.; Dandekar, T. \& Wolf, M. (2008): Synchronous visual analysis and editing of RNA sequence and secondary structure alignments using 4SALE. - BMC Research Notes 1: 91.

Shoup, S. \& Lewis, L.A. (2003): Polyphyletic origin of parallel basal bodies in swimming cells of chlorophycean green algae (Chlorophyta). - J. Phycol. 39: 789-796.

Schwarz, K. (1979): New soil algae from Dalmatia. Plant Syst. Ecol. 131: 193-210.

ŠKALOUD, P.\& PeKSA, O. (2010): Evolutionary inferences based on ITS rDNA and actin sequences reveal 
extensive diversity of the common lichen alga Asterochloris (Trebouxiophyceae, Chlorophyta). - Mol. Phylogenet. Evol. 54: 36-46.

StARR, R.C. (1954): Reproduction by zoospores in Planktosphaeria gelatinosa G.M. Smith. Hydrobiologia 6: 392-397.

STARR, R.C. (1955): A Comparative Study of Chlorococcum Meneghini and other spherical, zoospore-producing genera of the Chlorococcales. - 111 pp., Indiana University Press, Bloomington.

Swofford, D.L. (2002): PAUP*. Phylogenetic analysis using parsimony (*and other methods). Sinauer Associates, Sunderland MA.

VISCHER, W. (1936): Über heterokonten und heterokontenähnliche Grünalgen (Bumilleriopsis, Heterothrix, Heterococcus, Dictyococcus, Muriella). - Ber. Schweiz. Bot. Ges. 45: 372-410.

White, T. J.; Bruns, T.; Lee, S. \& TAylor, J.W. (1990): Amplification and direct sequencing of fungal ribosomal RNA genes for phylogenetics. In: InNIS, M.A.; Gelfand, D.H.; SNINSKY, J.J. \& White, T. J (eds): PCR protocols: A guide to methods and applications. - pp. 315-322, Academic Press, Inc., New York.
Wilgenbusch, J.C.; Warren, D.L. \& Swofford, D.L. (2004): AWTY: A system for graphical exploration of MCMC convergence in Bayesian phylogenetic inference. - http://ceb.csit.fsu. edu/awty

ZACHLEDER, V. \& CEPÁK, V. (1987): Visualization of DNA containing structures by fluorochrom DAPI in those cells which are not freely permeable to the dye. - Algological Studies 47: 157-168.

ZwickL, D. J. (2006): Genetic algorithm approaches for the phylogenetic analysis of large biological sequence datasets under the maximum likelihood criterion. - Ph.D. dissertation, The University of Texas at Austin.

(C) Czech Phycological Society (2012)

Received March 30, 2011

Accepted July 7, 2011 